\title{
Independent Ethics Committee Applicant
}

National Cancer Institute

\section{Source}

National Cancer Institute. Independent Ethics Committee Applicant. NCI Thesaurus. Code C127531.

The person responsible for the independent ethics committee application. 